\title{
A comparative study of urban occupational structures: Brazil and United States
}

\author{
Clauber Eduardo Marchezan Scherer ${ }^{*}$ \\ Pedro Vasconcelos Maia do Amaral ${ }^{\star *}$ \\ David Folch $^{\star \star \star}$
}

This paper compares the occupational structure of cities in Brazil and United States aiming to evaluate the extent to which the economic structure of these urban agglomerations is associated with the different stages of development, specifically when comparing a rich country with a developing one. Using a harmonized occupational database and microdata from the Brazilian 2010 Demographic Census and the U.S. American Community Survey (2008-2012), results show that Brazilian cities have a stronger connection between population size, both with occupational structure and human capital distribution, than the one found for cities in the United States. These findings suggest a stronger primacy of large cities in Brazil's urban network and a more unequal distribution of economic activity across cities when compared to USA, indicating a strong correlation between development and occupational structure.

Keywords: City network. Occupational structure. Brazil. United States.

\footnotetext{
* Porto Alegre City Hall, Porto Alegre-RS, Brazil (clauberscherer@yahoo.com.br; https://orcid.org/0000-0003-0596-7053).

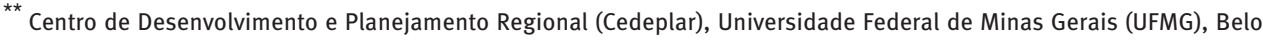
Horizonte-MG, Brazil (pedroamaral@cedeplar.ufmg.br; https://orcid.org/0000-0002-2505-035X).

*** Department of Geography, Planning and Recreation, Northern Arizona University, Flagstaff, Arizona, USA (david.folch@ nau.edu; https://orcid.org/0000-0002-8167-1118).
} 


\section{Introduction}

Cities are the engines of growth for national economies. The agglomeration advantages that they generate, and that constitute their main reason for existence, make these spaces attractive to both the most talented workers and most productive firms, creating an environment favorable to growth and development. Through high density, cities facilitate better sharing, matching and learning of people and companies in a process that boosts economic progress (DURANTON; PUGA, 2004). In addition, the sheer concentration of people leads to potential new outcomes because, as Marshall (1890) said, ideas are "in the air."

The functional role played by each city in an urban-system is related to its capacity to offer more specialized goods and services to the surrounding areas ( $\mathrm{LOCCH}, 1964$; CHRISTALLER, 1966). Since population growth increases the capacity to generate economies of agglomeration and market potential, population size is also related to the centrality level of the cities, potentially affecting their role in the urban network. Moreover, given utility's preference for diversity, enhanced access to a broader range of goods and services leads to higher welfare levels and development.

The interregional labor division and occupational structure of a given place also play an important role on its demographics. The proportion of females working in nondomestic and nonagricultural sectors is shown to affect fertility rates (TEITELBAUM, 2014). In addition to this, regional age-standardized mortality rates are significantly affected by occupational structure (KIBELE, 2012). However, the most important aspect of occupational structure and population dynamics is how it affects migration differentials and selectivity by cofactors such as educational level, age, gender and other individual factors (DE JONG; GARDNER, 2013). As Barufi (2015) shows, not only city size, but also sectorial composition is crucial to explain locational choices. Given the occupational structure, the static and dynamic effects of agglomeration economies are reinforced by a workforce selection process. Initial and return migrations are key to explain skilled workers selection (BARUFI, 2015). Hence, the occupational structure of a given locality is very important to determine its populational growth and dynamics.

However, growth in size is not followed only by the benefits associated with specialization (MARSHALL, 1898) and/or diversification (JACOBS, 1969). Unplanned urban expansion can create dynamics which stifle the agglomeration benefits of cities, since it precipitates problems related to pollution, congestion, segregation, sprawl and other unintended consequences. These inefficiencies tend to increase with city size, especially if urbanization is not properly managed and cities do not offer essential public infrastructure. In other words, "cities can become victims of their own success and the transformative force of urbanization can be attenuated" (UNITED NATIONS, 2016, p. 32).

Understanding the role of cities has become more urgent as migration to urban locations increases around the world. In OECD countries, for example, two out of three people live in cities with a population of 50,000 and above (OECD, 2014). A United Nations Report (2016) 
projects that the world's urban population in 2050 will be approximately 66 percent, with the most accelerated rates of urbanization happening in underdeveloped or developing countries, i.e., places that have a different development pattern than the USA and Western Europe. As pointed by Chauvin et al. (2017), the rapid growth of these localities creates a knowledge mismatch for urban economists and urban theory predominantly focused on cities of the "wealthy west."

These facts point out the necessity to create cross-country comparisons to investigate and understand the differences and similarities between cities from rich and poor countries. ${ }^{1}$ Simply importing successful urban or economic strategies into developing country cities ignores the context of both the importing and exporting locations. Comparative research constitutes a framework to achieve policies which focus the paths of cities on those external policies that best match their context.

Therefore, the main objective of this paper is to compare the urban agglomerations of Brazil and the United States of America (USA) using occupational composition and relating that with city size to identify similarities and differences in the urban structure of both countries. Even with the growing importance of this topic on urban economics, a scarcity of empirical work attempting to understand cross-national variation between cities and their place in the urban hierarchy beyond simple city-size approaches remains. ${ }^{2}$

The comparison between Brazil and United States is important as it allows us to compare the occupational structure of countries with very different development levels, but reasonably similar geographic and populational structure. Given that development is closely related to the provision of modern and diverse goods and services, our hypothesis is that the occupational and city-size structure of the two will reflect the difference in development levels. Given regional development inequalities, we expect the large urban agglomerations in both countries to show more similar occupation structures, whilst smaller cities are likely to show very different patterns, with greater homogeneity in the US in comparison with Brazil. The results shown in this study confirm our initial hypothesis but show that the occupational structure in the two countries is much more different than we anticipated.

This paper is structured as follows: section 2 shows how it is possible to establish a comparative base for occupational job structure and cities between Brazil and USA. section 3 presents the main results and discussion in a comparative framework between these two countries, stressing the occupational structure, its similarities and differences related to human capital and city size; and section 4 offers some concluding remarks and identifies potential paths of investigation for further research.

\footnotetext{
${ }^{1}$ Or, as some researchers prefer, between the Global South and Global North. See Roy (2009).

2 For details, see Gabaix and loannides (2004). Some examples of empirical works considering Brazil and/or the United States are Ruiz (2005), Matlaba et al. (2013) and Chauvin et al. (2017).
} 


\section{Occupational structure in Brazil and the United States}

In the context of this paper, the choice of comparing the occupational structure of Brazil and United States is based on the objective of comparing two countries at different development stages. In terms of developed nations, there are scarce examples of other countries with similar geographic and population size as Brazil. In fact, these two nations have the fourth (USA) and fifth (Brazil) largest land areas in the world ${ }^{3}$ and a fairly comparable population size, ${ }^{4}$ making this pairing appropriate for the comparison of city structure in a developing nation and a developed one.

Any attempt to create an international comparison using different data sources brings challenges and important decisions that need to be made. Therefore, given the aim of this paper, it is important to clarify how it is possible to generate a harmonized framework that allows for the comparison of the occupational structure of United States and Brazil.

\section{Data source}

The Brazilian data used in this study come from publicly available microdata from the Censo Demográfico 2010, the official national census conducted every ten years. Each observation in this representative sample has a weight, which allows individuals to be summed to construct socioeconomic profiles of cities. Individual observations can be easily aggregated to provide the average characteristics of each municipio - an administrative entity with relative autonomy subordinated to States.

One additional challenge that emerges is related to urban agglomerations. For example, it does not make sense to evaluate the economic structure of the city of São Paulo without taking into consideration its neighborhood. The hinterland of São Paulo has a strong connection to the city in terms of commuting to work, study or commercial activity. The spatial distribution of workers and activities in urban agglomerations is not random. Disregarding this would be very misleading. The same applies to agglomerations in USA.

To address this issue, we aggregate some cities in agglomerations following IBGE's study Arranjos Populacionais e Concentrações Urbanas no Brasil (2015). It is important to highlight that such a study constitutes an important mark for Brazil, ${ }^{5}$ because the urban agglomerations defined by it are based on data on population density and work/study flows, a less arbitrary rule compared to metropolitan areas and conceptually closer to the definition of agglomerations used in the US. To avoid having to refer to these agglomerations and single cities differently, in this study we use the terms city and urban agglomerations interchangeably.

\footnotetext{
${ }^{3}$ In overall land territory, the USA is bigger than Brazil, but here only continental USA is considered - represented by 48 States as showed in Map 2 - which makes Brazil a little bigger then USA.

${ }^{4}$ According to census data for each country, in 2010 USA had 308 million people and Brazil 190 million.

${ }^{5}$ Prior to this, Brazil had the Região de Influência das Cidades (REGIC) that tried to establish centrality of cities.
} 
Regarding US data, in 2005 the United States switched from a decennial census model to an annual data collection model (SPIELMAN et al., 2014). While the decennial census is still in place for building a complete enumeration of the population and collecting a few basic demographic characteristics, ${ }^{6}$ the American Community Survey (ACS) is now the source for detailed socioeconomic information on households. This uninterrupted inquiry produces estimated characteristics ${ }^{7}$ for the entire country. Data are currently published in a 1-year base that is statistically representative of geographic areas above 65,000 people and 5-year base, which is representative of subareas of the country.

The corresponding microdata are available via Public Use Microdata Sample (PUMS), where the most detailed unit of geography is the Public Use Microdata Area (PUMA). PUMAs are special non-overlapping areas that partition states into contiguous geographic units containing no fewer than 100,000 people each. These statistical areas do not map exactly onto USA counties, the geographic unit most similar to Brazilian municipios.

As already mentioned, in this study, some cities are aggregated in urban agglomerations when they have a strong connection between them. For the USA, this characterization is obtained via Core Base Statistical Areas (CBSA), which group counties based on contiguity, density of people and intensity of flows to work. Since the use of microdata requires using PUMAs instead of counties, this study employed a classification provided by the Missouri Census Data Center that approximates CBSA geographies using PUMAs.

It is important to emphasize the similarity between Brazilian Arranjos Populacionais and North American Core Base Statistical Areas (CBSA). Both are based on the principle that contiguous municipios/counties that have strong connections with a core urban area should be analyzed as a unique space. Moreover, both consider the intensity of commute observed between the core area and the interconnected one as a measure of interconnectivity.

Bringing all these pieces together and aiming to match the Brazilian data as closely as possible, this study uses 5-year base ACS data centered in 2010. More specifically, ACS 2008-2012 was used, which is a multiyear combination of the 1-year PUMS files with appropriate adjustments to the weights and inflation factors. In addition, the minimum agglomeration size considered for both countries is 100,000 inhabitants.

\section{Occupational crosswalk}

With the agglomerations and data sources established, the final concern is about occupational structure of workers. Brazil's census classifies occupational positions of working people (variable V6461) according to the Classificação de Ocupações para Pesquisas Domiciliares 2010 (COD). In the United States, the ACS occupational position (variables OCCP02, OCCP10, OCCP12) is classified using the Standard Occupation Classification 2010 (SOC). Since there is no direct crosswalk between these two, a classification system from

\footnotetext{
${ }^{6}$ Starting in 2010, the census focuses on age, sex, race, Hispanic origin, family status and home ownership.

${ }^{7}$ That is a crucial aspect in ACS. Since there is continuous inquiry on fractions of households around the nation, it can produce reliable distributional characteristics but not counts of USA
} 
the International Labor Organization, International Standard Classification of Occupations 2008 (ISCO) was used for linkage.

The Brazilian COD and the ISCO already maintain high compatibility ${ }^{8}$ so these two databases were easily harmonized. ${ }^{9}$ The U.S. Bureau of Labor Statistics provides a conversion table between SOC and ISCO that allows for a direct conversion of $94 \%$ of all USA occupations when grouped into a two digits ISCO base. Therefore, it was possible to create comparative classes of occupations between those two countries employing a crosswalk strategy that used ISCO as the bridge between the two.

Finally, it is important to note that this study only included employed people between 24 and 65 years old that received money from their work and for whom it was possible to identify the occupational category of their job. Whenever necessary, Brazilian salaries were adjusted using dollar currency of July of 2010. In the case of the US, personal wages were converted in a monthly base and adjusted to 2010 .

\section{Results and discussion}

\section{Urban hierarchy}

As shown in Table 1, in 2010 Brazil had 185 urban agglomerations with population above 100,000, which together concentrated 60 percent of the country's overall inhabitants. As highlighted in Map 1, São Paulo and Rio de Janeiro, which together are home to more than 31 million residents, occupy the top positions. Considering the fact that Brazil does not have any agglomerations between 5 and 10 million people increases the relevance of these two cities in Brazil's city-network.

TABLE 1

Distribution of population by size of urban agglomerations Brazil and USA - 2010

\begin{tabular}{lcccrcc}
\hline \multirow{2}{*}{ Populational size } & \multicolumn{2}{c}{ Brazil } & & \multicolumn{2}{c}{ USA } \\
\cline { 2 - 3 } \cline { 5 - 6 } & Total & Population (\%) & & Total & Population (\%) \\
\hline 10 million or more & 2 & 27.56 & - & & 2 & 12.55 \\
5 million to 10 million & 17 & 35.08 & & & 72 & 17.14 \\
1 million to 5 million & 166 & 37.36 & & 295 & 35.58 \\
100 thousand to 1 million & & & & & 34.72 \\
\hline
\end{tabular}

Source: Own elaboration.

The next category (1 - 5 million) highlights the importance of state capitals in the city-network structure of Brazil. All 17, except MSA of Campinas and Baixada Santista, both closely related to São Paulo dynamics, are capitals, including the national capital Brasilia.

\footnotetext{
${ }^{8}$ All groups are consistent at 2-digit level in which eight of ten groups are compatible at four digits scale.

${ }^{9}$ The final results converting the four-digits Brazilian's occupations to a two digit SOC base can be seen in the Appendix of this work.
} 
The last category shows sparse points representing the small agglomerations that have relevance in a regional context for the Brazilian economy.

As Map 1 points out, it is not difficult to recognize a regional pattern in Brazil: a high density of cities of all categories located in the Southeast; while at same time the North and Northeast reflect a pattern of dispersed and disconnected places, where almost all larger points are state capitals. This regionally imbalanced composition reflects a long-term trend in the Brazilian economy. Among the many factors helping to explain it is the regional path followed by the industrialization process which concentrated in an "industrial polygon" as pointed out by Diniz (2003), sprawling in areas that cover a significant fraction of the agglomerations in the map below.

In 2010, the USA had 346 agglomerations that together represented approximately 84 percent of overall population, a result that, when compared with Brazil, reveals simultaneously a more concentrated, but as can be seen in Map 2, a more sprawling country. Another important fact is that US cities can be considered relatively well distributed throughout the country. At the top of the hierarchy are New York and Los Angeles, which, together, have 32 million residents, a number similar to the top two cities in Brazil. In contrast to Brazil, the USA has seven cities - Chicago, Boston, Washington, Atlanta, Miami, Houston and Dallas - in the 5 to 10 million inhabitant category.

MAP 1

Brazilian city-network structure by size and distribution - 2010

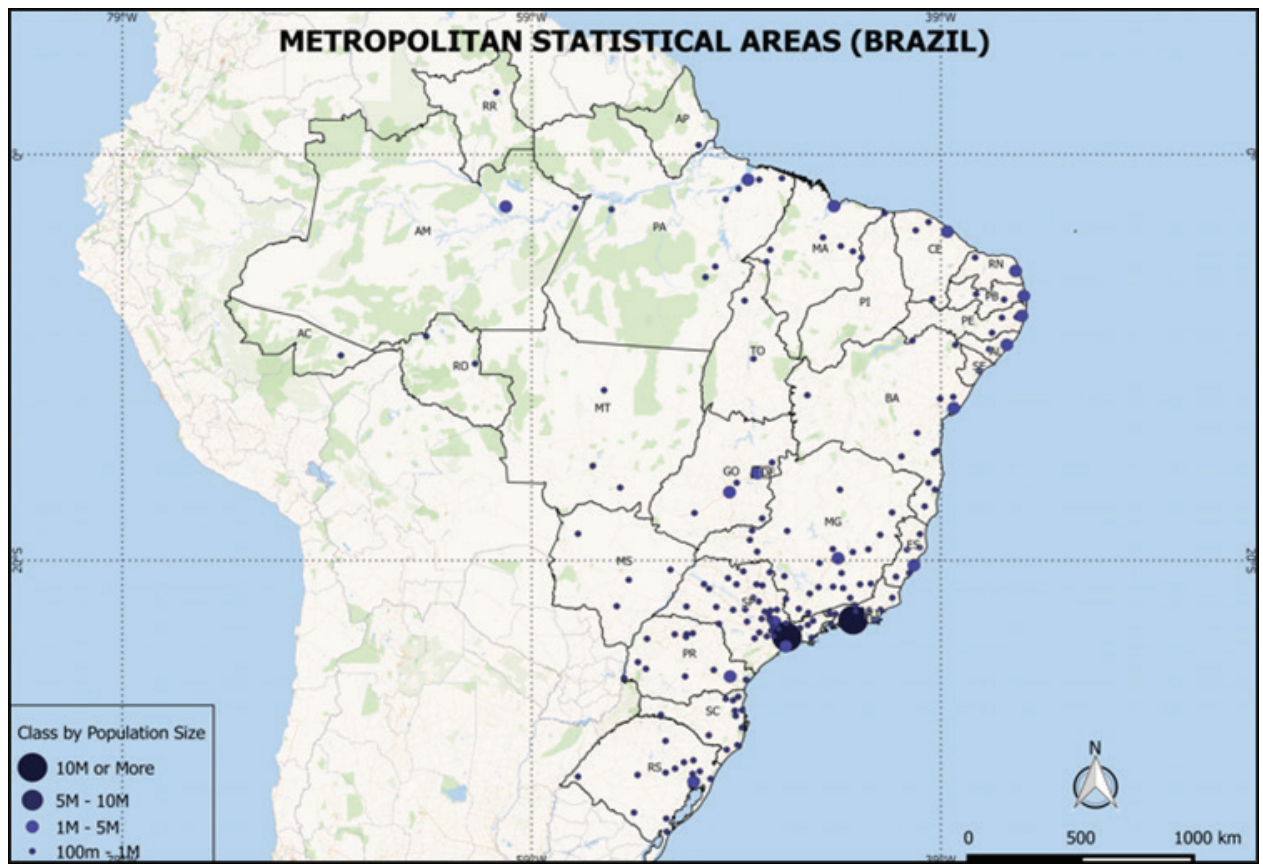

Source: Own elaboration. 
MAP 2

North American city-network structure by size and distribution - 2010

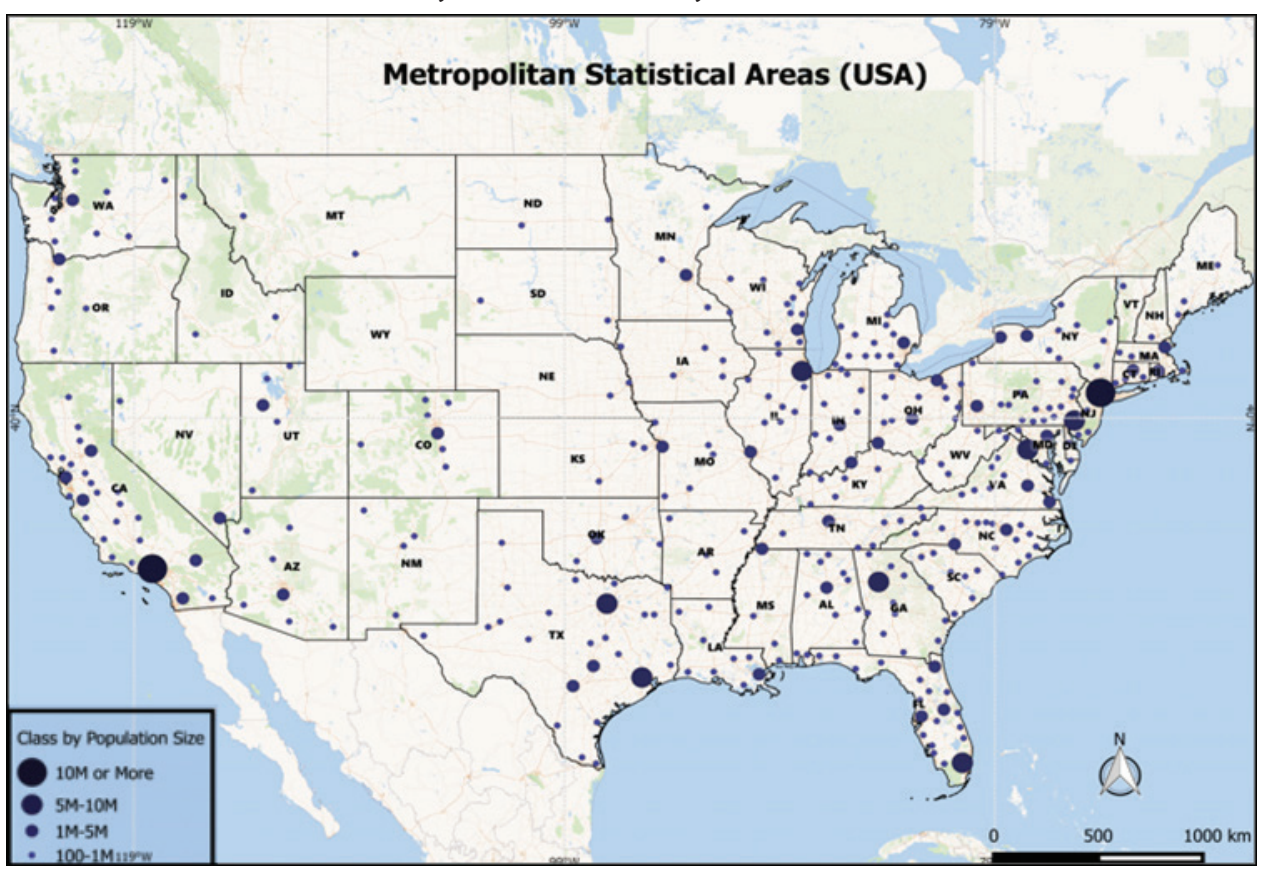

Source: Own elaboration.

As observed by Ruiz (2005), even when adjusted to the North American population, Brazil has a more unbalanced city-network without a smooth transition between large and small places. From a regional perspective, Map 2 also highlights the agglomeration of points in the Northeast, which represents a long established and economically important part of the nation. At the same time, the center of the country, the Great Plains and Mountain West for example, represent a more sparsely populated space.

For both countries, it is visually clear that coastal areas play a strong role in city dispersion, an argument previously noted by Rappaport and Sacks (2003) when analyzing long trends in economic growth. Furthermore, for both countries, the spatial distribution presented in the maps is closely related to their migration patterns. For example, the US railroad system development that started around 1850 helped to connect the already established East to a rapidly growing Midwest and West (ATACK et al., 2010; DONALDSON; HORNBECK, 2016).

Brazil also had a latter occupation of its western lands, but much more recently than in the US - especially in 1960s and 1970s - and mainly driven by farming activities. That movement enabled the emergence of a corridor of occupation and development in the country borders (CUNHA, 2002) and helped improve Brazil's city-network composition.

Notwithstanding, these results highlight an institutional difference that goes back to the colonial times of these two countries and that affects their spatial economic development 
in uneven ways (GALIANI; KIM, 2008; KIM; LAW, 2012). While in Brazil from top 25 MSAs, 22 are State capitals, in the US, only 7 belong to that group. Although in both cases the national capitals were cities built on purpose and do not occupy the first places in the urban hierarchy, the primacy exerted by Sao Paulo and Rio de Janeiro - as the distance in populational size between them and the next group of cities - along with the prominent position of state capitals in Brazil's city-network point out a difference between them.

\section{Human capital}

While institutional paths have a strong link to the current shape of the city-network, the focus here is on the employment structure and human capital across the respective city-networks. Human capital stocks, using educational attainment as a proxy, are displayed in Figure 1. In 2010, nearly 50\% of Brazil's employed population had finished middle school at most, while in the US, more than $94 \%$ of workers completed at least high school. If understood as an overall productivity measure of nations, this helps explain the huge gap in median monthly wages received in each country after being sorted by educational attainment.

In both countries, wages rise with education, which indicates an increase in productivity as workers improve their knowledge. Moreover, the ratio between Brazilian and US wages shows a converging trend: starting at 3.93 for high school going down to 1.60 for people with doctorate degrees. This converging pattern does not hold if the two lowest skill groups are included, which is likely explained by the large pool of workers in Brazil in these groups, making replacement easy and thus keeping the salary for both groups closer.

FIGURE 1

Educational composition by share and median monthly salaries Brazil and USA - 2010

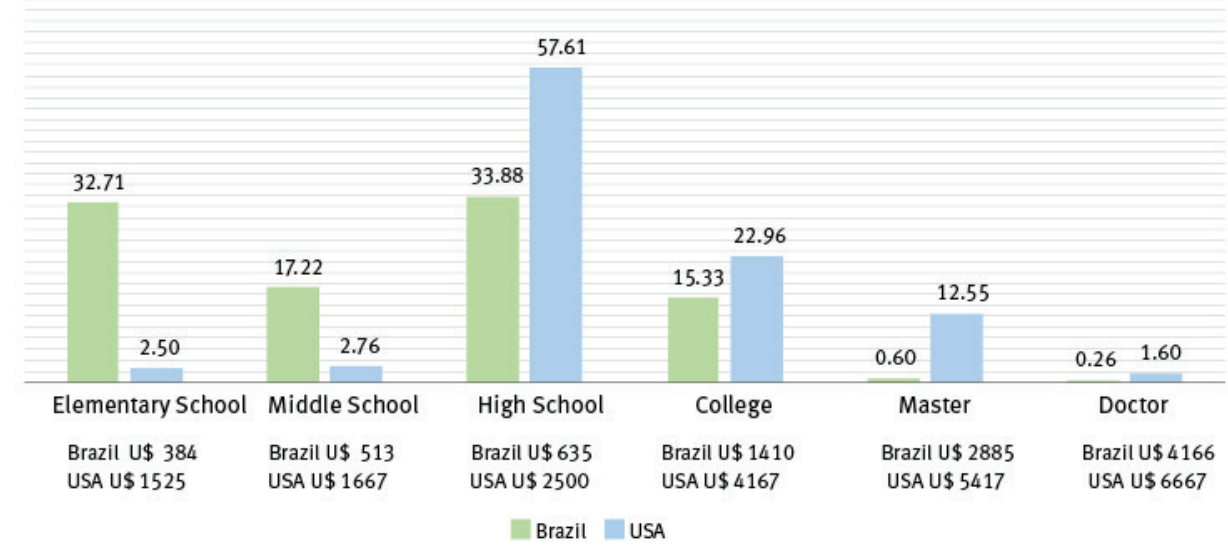

Source: Own elaboration.

Regarding within country ratios, the countries are quite different. In the US, the jump from middle school to high school education represents a half again increase in wages; 
and then a slightly more than half again increase (62.5\%) for the next jump to bachelor's degree. However, in Brazil the high school diploma only buys a $23 \%$ increase in wages over middle school, but the bachelor's degree results in more than a doubling of wages $(122 \%)$ over a high school diploma. We hypothesize that these different patterns represent signaling to employers.

The meaning of a high school diploma in the USA is relatively similar across the country and as such is a clear signal of a minimum competence level. More importantly, a high school diploma is so common in the USA that not having the degree is a strong negative signal in the job market. In contrast, the Brazilian high school diploma does not carry the same consistent signal in terms of skills attained. With so many workers lacking the designation in Brazil, employers have likely developed other screening techniques when selecting among candidates for low to medium skill jobs. The bachelor's degree in the USA is another clear signal of skills attained, and brings with it a similar proportional increase in wages. In Brazil, the share of the population with a bachelor's degree is substantial but still relatively small and people with higher degrees (master's degrees and doctorates) represent a tiny share of the labor pool. The bachelor's degree becomes the dominant distinguishing signal a worker can make on the job market and thus has twice the effect as in the USA.

\section{Occupational distribution}

The previous analyses showed that although having some similarities in land area and population size, there is a large gap between the countries in socioeconomic characteristics and city-network composition. Given the established links between educational attainment, wages and productivity, disproportionality in regional distribution of types of workers represents an important indicator for larger regional imbalances. Therefore, this section considers the regional variation in occupations and its connection to city size and education.

The approach proposed here complements that from the Urban Wage Premium (UWP) literature. The core objective of UWP research is to identify the extent to which the density of economic activity in cities influences workers' productivity and to disentangle this effect from a sorting effect, unobserved individual characteristics and spatial heterogeneity (HEUERMANN et al., 2010). Basically, if higher urban prices do not fully account for the higher nominal wages, i.e., if a real wage difference exists, then it is expected that workers in larger cities are more productive (GLAESER; MARE, 2001).

In contrast to those studies that focus on determining the fraction of wages that could be associated with individual and agglomerative effects, here the emphasis is on cities as a unit and more precisely on their occupational composition and human capital structure. In addition, this paper investigates how this structure can be related to different development stages of cities, using population size as a proxy, irrespective of whether the city is in a developed or developing country. 
Even though jobs associated with high skilled workers tend to be more concentrated in big cities for both countries, those results are both tempered by different patterns at the regional scale and by human capital pattern of these nations. Together, these facts raise two hypotheses: (i) employment structure of cities has a divergent pattern between nations and (ii) size plays a different role in each of them.

Based on the previous hypotheses, an important question to investigate is how the employment composition variation among cities can be related to their size and human capital distribution, both within and between countries. Understanding how each citynetwork responds to increases in city size is a valuable tool to help in the design of policies. Krugman's Dissimilarity Index ${ }^{10}$ (KRUGMAN, 1991) is used to investigate this issue; the measure can be traced back to Duncan and Duncan (1955), which used this framework to understand racial segregation, i.e., racial dissimilarity. The measure is used here to capture the dissimilarity in occupational structure between pairs of cities. The index ranges from 0 to 2 , with low values indicating city pairs that have similar employment distributions and high values for those pairs that are not alike.

Figure 2 shows results for three different inquiries using the index to compare each city to: a) the "average city", b) the largest city, c) the city with the highest concentration of high-skilled workers - chosen based on the location quotient ${ }^{11}$ for concentration of workers with college education and above - and d) the city with the lowest concentration of high-skilled workers. In all cases, the results are plotted against the log of population.

In Brazil's case, the negative association between occupational structure and city size is clear: as city size increases, dissimilarity decreases, implying convergence toward the national average. The USA also shows a negative trend, but far less pronounced. In addition, the average Brazilian city has and index of 0.25 and 18 cities are above 0.4 ; in contrast, these values are 0.20 and 3 in the USA indicating that occupational composition is far less variable in the USA relative to the national average.

The next pair of graphs show the dissimilarity between the largest city and the others, which, again, highlights the strong association with size in the Brazilian economy. The similarity between the first and second pairs of plots highlights the disproportional weight the largest cities have on the overall national employment distributions. Put together, these two results indicate that large cities tend to be more similar, as would be expected according to the literature (DURANTON; PUGA, 2000), but also tend to be much more different than other places in the Brazilian city-network.

\footnotetext{
${ }^{10} S I_{t j}=\Sigma_{k}\left|\frac{E_{k l}}{E_{l}}-\frac{E_{k j}}{E_{j}}\right|$ where $i$ and $j$ are cities and $k$ represent the occupational groups of the economy.

${ }_{11} Q L_{k t}=\frac{E_{k t}}{E_{t}} / \frac{E_{k}}{E}$ where $k$ indexes education level, $i$ indexes cities and $E$ is the employment count; no subscript implies
summation over all members of the category.
} 
FIGURE 2

Krugman index vs city size

Selected Units - 2010
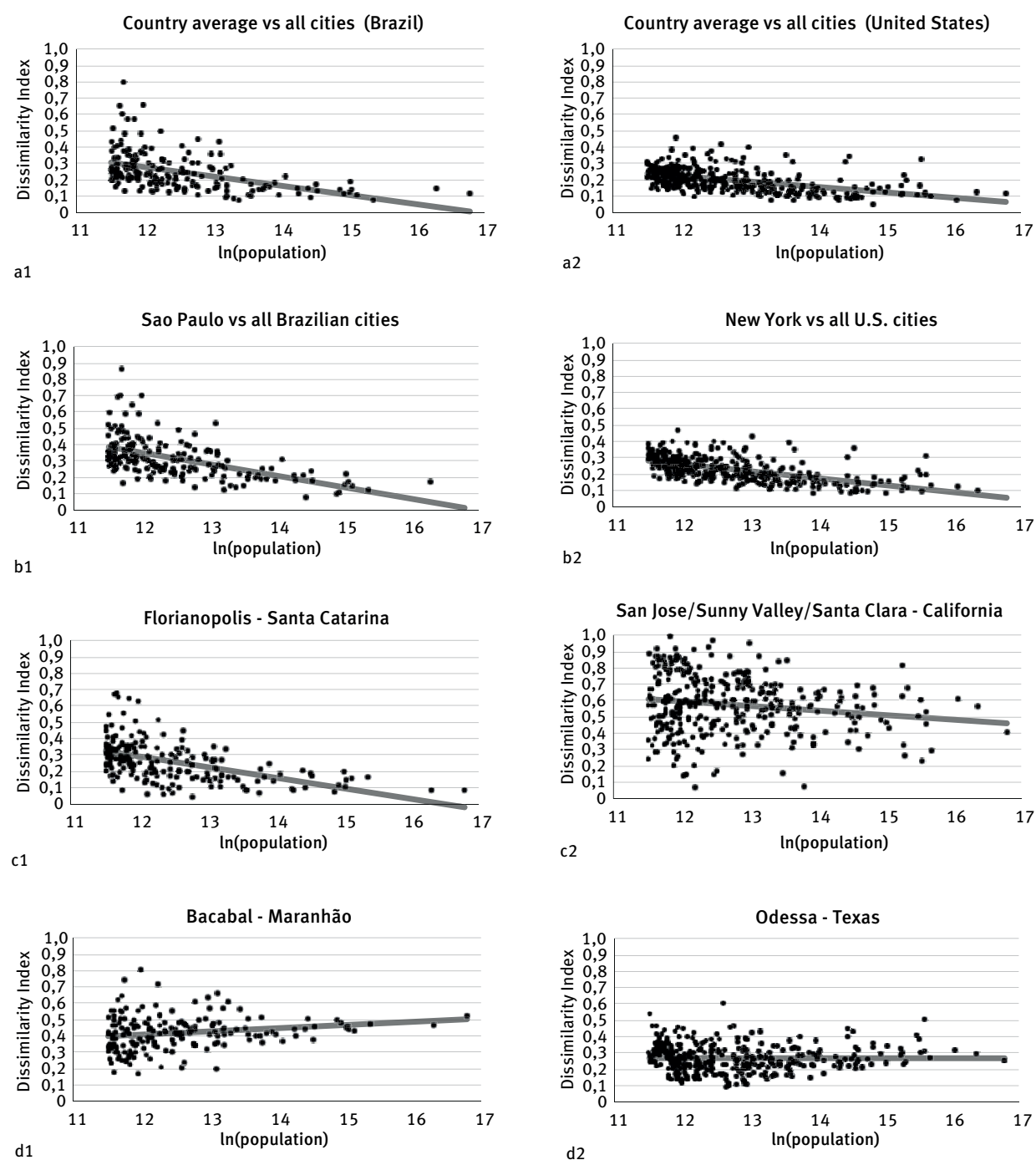

Source: Own elaboration.

Occupational dissimilarity relative to the most educated city in the USA presents a very different story. San Jose, California is the 34th largest city in the USA and the anchor of Silicon Valley's high-tech complex. The most noticeable trends are a reduction in variance as city size increases and that dissimilarity is converging to a level considerably above zero. In Brazil, the dissimilarity pattern generally matches that of the average and largest city, indicating convergence to low dissimilarity as city size increases. The city of Florianopolis is the 23th largest in Brazil and was ranked by the UN as having the third highest Human 
Development Index in Brazil. ${ }^{12}$ It should be noted that there are quite a few cities with indices below 0.1 at all city sizes.

The hypothesis of polarization in high-skilled workers in Brazil cities is reinforced when we analyze the lowest levels of human capital qualification, since dissimilarity increases with size. In turn, in the US, even the worst city in this scenario still shows a flat relation with others presenting a sprawl scheme of human capital.

At first glance, a reader could think that this variation with the biggest gap around $50 \%$ (since the index goes from 0 to 2 ) is not so expressive. However, it should be noted that a city is an organism that demands some fundamental functions - such as schools, food service, grocery stores and hospitals. Considering the fact that its structures could not be $100 \%$ different from each other, a $50 \%$ differentiation between two places is an expressive distinction.

As cities increase in size, it is generally expected that their economic structures become more diversified (JACOBS, 1969) by increasing participation of workers in more specialized services, for example. Therefore, as a final exploration, it is interesting to analyze how the effects of urbanization economies are related to size in these two countries. To investigate this issue, we adopt Florida's (2014) concept of Creative Class. ${ }^{13}$

These occupations represent $25 \%$ of the Brazilian economy and approximately $30 \%$ in the US. In both countries, they concentrate well paid and highly educated workers. While some correlation would be expected, high human capital and the Creative Class not necessarily represent the same workers and, more importantly, being part of the Creative Class has a bigger effect on wages - a key element of regional productivity - whereas education tends to have a greater effect on people's income (FLORIDA, 2014).

Figure 3 contains a biplot graph that shows the outcome of a Principal Components Analysis (PCA) based on the share distribution of each group of creative occupations for both countries. It is a useful tool since the angle formed by any two variables, represented as vectors, reflects their actual pairwise correlation. Also, on the graph, objects are distributed based on their similarity and attraction to each other.

Therefore, the size and direction of arrows represent the loadings for each one of the creative class occupations and the position of dots represents the combination of scores of the first two components for each city. Results were categorized accordingly with population classes previously employed in Maps 1 and 2, to analyze if a growth in population is related to a path in certain specialized group of occupations.

Moreover, in Figure 3 it is possible to note a significant differentiation between the occupational structure of the creative classes in Brazil and USA. The Brazilian agglomerations are concentrated in an upper-left diagonal triangle while US cities

\footnotetext{
12 Atlas do Desenvolvimento Humano no Brasil.

${ }^{13}$ It includes the following occupational groups: Computer and Mathematical; Architecture and Engineering; Life, Physical and Social Science; Education, Training and Library; Arts, Design, Entertainment, Sports and Media; Management; Business and Financial Operations; Healthcare Practitioners and Technical.
} 
concentrate in the lower-right one. While Management and Architecture/Engineering Occupations are the three activities most related to Brazilian cities, in the US Healthcare Practioners, Business/Financial and Computer/Mathematical are those more relevant to differentiate the occupational structure.

FIGURE 3

Biplot for principal component analysis for creative class Brazil and USA - 2010

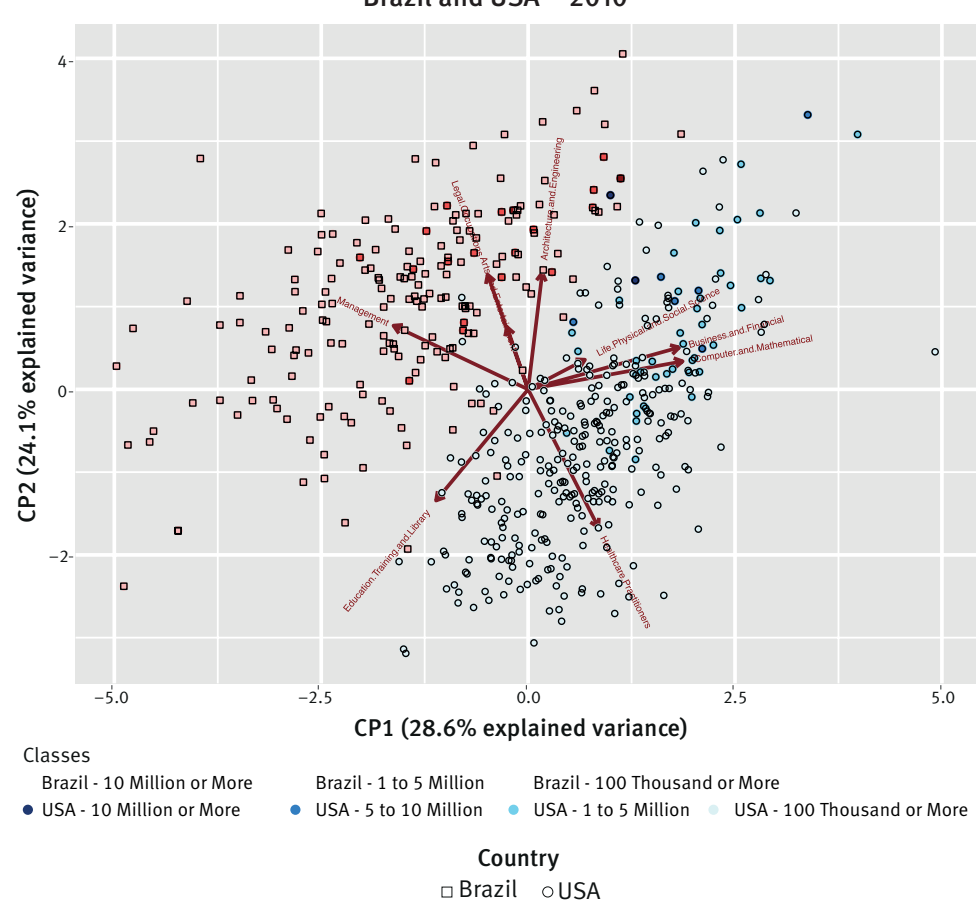

Source: Own elaboration.

On the other hand, in both countries Education Training and Library occupations are associated with the smallest agglomerations. The small vectors are related to Art and Entertainment and Life Physical Social Science and indicate that these categories do not contribute significantly to explain the occupational structure differentiation.

Table 2 presents the average score by country and class of cities based on the first two components. This is used as a proxy to analyze the average city on certain group based on the size for each country. If these results are seen as coordinates to a vector that follows city growth, it is possible to note a different pattern between those two countries while the cities grow.

The biggest cities (three classes running from 1 to 10 million) tend to be concentrated in the first quadrant, which represents positive values for both Component 1 and Component 2. However, while scores in the US reveal a greater influence of Business and Financial, Computer and Mathematical, for Brazil it tends to be closer to Architecture and Engineering. 
The largest difference between countries is associated to their agglomerations running from 100 Thousand to 1 Million groups, where the average city has a different signal for Component 1 and Component 2. While in Brazil they are predominantly concentrated in the second quadrant, led by Management and Legal Occupations, in the US, they are in the fourth quadrant, where Health Care Practitioners play an important role.

TABLE 2

PCA average scores by group of cities (first and second components) Brazil and USA - 2010

\begin{tabular}{|c|c|c|c|c|c|c|c|c|}
\hline \multirow[t]{2}{*}{ Country } & \multicolumn{2}{|c|}{10 million or more } & \multicolumn{2}{|c|}{5 to 10 million } & \multicolumn{2}{|c|}{1 to 5 million } & \multicolumn{2}{|c|}{$\begin{array}{c}100 \text { thousand } \\
\text { to } 1 \text { million }\end{array}$} \\
\hline & $C P 1$ & $C P 2$ & $C P 1$ & $C P 2$ & $C P 1$ & $C P 2$ & $C P 1$ & $C P 2$ \\
\hline Brazil & 0.469 & 2.356 & - & - & -0.482 & 1.642 & -1.583 & 0.975 \\
\hline USA & 1.145 & 1.832 & 1.880 & 1.335 & 1.837 & -0.697 & 0.601 & -0.803 \\
\hline
\end{tabular}

Source: Own elaboration.

As the results show, in terms of Creative Class these two countries have some similarity related to their biggest cities, also highlighted by the closeness of scores for Sao Paulo and New York, the two biggest cities in both countries. On the other hand, they present an increasing differentiation towards smaller agglomerations, which indicates that city growth does not necessarily mean specialization in terms of high order activities developed in cities.

Put together, these results indicate that in Brazil, city size plays a more central role for both economic composition and concentration of high-educated workers than it does for the United States. Since big cities in both countries converge to a similar occupational structure which is related to high-skill/high-paid employees, whereas smaller agglomerations show a very distinct structure, this fact can be related to regional imbalance that tends to be exacerbated with time, evidencing a different city development patterns between the developed and developing world.

\section{Conclusion}

This paper creates comparative parameters for cities in two global important but different national economies: Brazil and the United States. With that aim, this work offers an occupation category crosswalk that enables future studies to compare these two countries in other ways than those followed here. Furthermore, this paper investigates the city patterns of these two countries through size, occupational structure and human capital stock. Understanding why and how cities are different in distinct contexts can be a useful approach to designing more precise strategies.

At first glance, some signs of similarity can be identified, e.g., land area, population and overall occupational structure, but when analyzed at the city level, differences between countries arise. The patterns of these two nations diverge substantially when considering their city-network structure. The USA presents a smoother transition between its larger 
and smaller places then Brazil. In addition, in job composition and human capital, results show that in Brazil, population size tends to play a much more important role than it does in the United States. Together, and considering the spatial distribution of cities in Brazil, these facts point to an important element of regional imbalance.

An interesting step forward would be to look at different patterns in wage inequality between the cities of these two countries. As a city grows, it makes sense to consider the possibility that wage inequality rises with that, since it reflects the divided job market of cities, where knowledge workers make much more money than service and working classes. But given the diverging patterns related to human capital in these two countries, and the convergence of economic structure and high skill workers in big cities in Brazil, it would be interesting to investigate in what dimension this inequality can be disentangled from the tension between the growing concentration of talent workers and low paid service jobs.

As pointed out in the beginning of this paper, the highest rates of urban growth in the next few years will come from underdeveloped and developing countries, places which urban economists generally have just a vague understanding of, including how they relate to each other. This is a big challenge to academic researchers and policy makers around the world interested in cities. In that regard, this paper contributes to bridging that divide.

\section{References}

ATACK, J.; BATEMAN, F.; HAINES, M.; MARGO R. Did railroads induce or follow economic growth? Urbanization and population growth in the American Midwest, 1850-60. Social Science History, v. 34, n. 2, p. 171-197, 2010.

CHAUVIN, J.; GLAESER, E.; MA, Y.; TOBIO, K. What is different about urbanization in rich and poor countries? Cities in Brazil, China, India and the United States. Journal of Urban Economics, v. 98, p. 17-49, 2017.

CHRISTALLER, W. Central places in southern Germany. Englewoods Cliffs, 1966.

CUNHA, J. M. P. da. A migração no Centro-Oeste brasileiro no período 1970-96: o esgotamento de um processo de ocupação. Campinas: Núcleo de Estudos de População/Unicamp, 2002.

DINIZ, C. Desenvolvimento poligonal no Brasil: nem desconcentração, nem contínua polarização. Nova Economia, v. 3, n. 1, p. 35-64, 2003.

DONALDSON, D.; HORNBECK, R. Railroads and American economic growth: a "market access" approach. The Quarterly Journal of Economics, v. 131, n. 2, p. 799-858, 2016.

DUNCAN, D.; DUNCAN, B. A Methodological analysis of segregation indexes. American Sociological Review, v. 20, n. 2, p. 200-210, 1955.

DURANTON, G.; PUGA, D. Diversity and specialisation in cities: why, where and when does it matter? Urban Studies, v. 37, n. 3, p. 533-555, 2000.

DURANTON, G.; PUGA, D. Micro-foundations of urban agglomeration economies. In: HENDERSON, V.; THISSE, J. F. (org.). Handbook of regional and urban economics cities and geography. Amsterdam: North Holland, 2004. p. 2063-2117, 2004.

FLORIDA, R. The rise of the creative class, revisited. New York: Basic Books, 2014. 
GABAIX, X.; IOANNIDES, Y. M. The evolution of city size distributions. In: HENDERSON, V.; THISSE, J. F. (org.). Handbook of regional and urban economics cities and geography. Amsterdam: North Holland, 2004. p. 2341-2378.

GALIANI, S.; KIM, S. Political centralization and urban primacy. In: COSTA, D.; LAMOREAUX, N. (org.). Understanding long-run economic growth. Chicago and London: The University of Chicago Press, 2008. p. 121-154.

GLAESER, E.; MARÉ, D. Cities and skills. Journal of Labor Economics, v. 19, n. 2, p. 3316-3402, 2001. HEUERMANN, D.; HALFDANARSON, B.; SUEDEKUM, J. Human capital externalities and the urban wage premium: two literatures and their interrelations. Urban Studies, v. 47, n. 4, p. 749-767, 2010. HOOVER, E. The location of economic activity. McGraw-Hill, 1948.

JACOBS, J. The economy of cities. Random House, 1969.

DE JONG, G. F.; GARDNER, R.W. Multidisciplinary approaches to microlevel studies in developed and developing countries. Elsevier Science, 2013.

KIBELE, E. Regional mortality differences in Germany. Demographic Research Monographs, Springer Netherlands, 2012.

KIM, S.; LAW, M. History, institutions, and cities: a view from the Americas. Journal of Regional Science, v. 52, n. 1, p. 10-39, 2012.

KRUGMAN, P. Geography and trade. MIT Press, 1991.

LÖSCH, A. The economics of location. Yale University, 1964.

MARSHALL, A. Principles of economics. Cosimo, 1898.

MATLABA, V.; HOLMES, M.; MCCANN, P.; POOT, J. A century of the evolution of the urban system in Brazil. Review of Urban \& Regional Development Studies, v. 25, n. 3, p. 129-151, 2013.

MORENO, J.; CLOS, J. Urbanization and development: emerging futures. UN Habitat, 2016.

OECD. OECD Regional outlook 2014. Regions and cities: where policies and people meet. Paris: OECD Publishing, 2014.

RAPPAPORT, J.; SACHS, J. The United States as a coastal nation. Journal of Economic Growth, v. 8, n. 1, p. 5-46, 2003.

ROY, A. The 21st-century metropolis: new geographies of theory. Regional Studies, v. 43, n. 6 , p. 819-830, 2009.

RUIZ, R. Estruturas urbanas comparadas: Estados Unidos e Brasil. Estudos Econômicos, v. 35, n. 4, p. 715-737, 2005.

SPIELMAN, S. E.; FOLCH, D.; NAGLE, N. Patterns and causes of uncertainty in the American Community Survey. Applied Geography, v. 46, p. 147-157, 2014.

UNITED NATIONS. World urbanization prospects: the 2014 revision. New York: United Nations Department of Economics and Social Affairs, Population Division, 2015.

TEITELBAUM, M. The British fertility decline: demographic transition in the crucible of the Industrial Revolution. Princeton University Press, 2014. 


\title{
About the authors
}

Clauber Scherer is Ph.D in Regional Economy (Universidade Federal de Minas Gerais) and legislative assistant at Porto Alegre City Hall.

Pedro Vasconcelos Maia do Amaral is Ph.D. in Land Economy (University of Cambridge) and tenured assistant professor at the Department of Economics, Universidade Federal de Minas Gerais.

David Folch is Ph.D in Geography (Arizona State University) and an assistant professor at the Department of Geography, Planning and Recreation, Northern Arizona University.

\section{Contact address}

\author{
Clauber Scherer \\ Porto Alegre City Hall \\ Av. Loureiro da Silva 255, Office 226 \\ 90013-901 - Porto Alegre-RS, Brazil \\ Pedro Vasconcelos Maia do Amaral \\ Cedeplar/Face, Universidade Federal de Minas Gerais \\ Av. Antônio Carlos, 6627, Pampulha \\ 31270-901 - Belo Horizonte-MG, Brazil \\ David Folch \\ Department of Geography, Planning and Recreation, Northern Arizona University \\ PO Box 15016 \\ 86011 - Flagstaff, Arizona, USA
}

\section{Resumo}

Estudo comparativo das estruturas ocupacionais urbanas: Brasil e Estados Unidos

Este artigo compara a estrutura ocupacional das cidades do Brasil e dos Estados Unidos, visando avaliar a extensão em que a estrutura econômica dessas aglomerações urbanas se associa aos diferentes estágios de desenvolvimento, especificamente quando se compara um país rico com um em desenvolvimento. Utilizando um banco de dados ocupacionais harmonizado e microdados do Censo Demográfico Brasileiro de 2010 e do US American Community Survey (2008-2012), os resultados mostram que as cidades brasileiras têm uma conexão mais forte do tamanho da população com a estrutura ocupacional e a distribuição de capital humano do que a observada em cidades nos Estados Unidos. Estes resultados sugerem uma primazia mais forte das grandes cidades na rede urbana do Brasil e uma distribuição mais desigual da atividade econômica entre as cidades quando comparadas aos EUA, indicando uma alta correlação entre desenvolvimento e estrutura ocupacional.

Palavras-chave: Rede de cidades. Estrutura ocupacional. Brasil. Estados Unidos. 


\section{Resumen}

Un estudio comparado de las estructuras ocupacionales urbanas: Brasil y Estados Unidos de Norteamérica

Este documento compara la estructura ocupacional de ciudades de Brasil y Estados Unidos de Norteamérica con el objetivo de evaluar la extensión a la cual la estructura económica de estas aglomeraciones urbanas se asocia en las diferentes etapas de desarrollo, específicamente cuando se compara un país rico con un país en desarrollo. Utilizando una base de datos ocupacional armonizada y microdatos del censo demográfico brasileño de 2010 y de la Encuesta de la Comunidad Estadounidense (2008-2012), los resultados muestran una conexión más fuerte en las ciudades brasileñas entre el tamaño de la población y la estructura ocupacional y la distribución del capital humano que la encontrada para ciudades de los Estados Unidos. Estos hallazgos sugieren una mayor primacía de las grandes ciudades en la red urbana de Brasil y una distribución más desigual de la actividad económica entre las ciudades en comparación con las de Estados Unidos, lo que indica una fuerte correlación entre el desarrollo y la estructura ocupacional.

Palabras clave: Red de ciudades. Estructura ocupacional. Brasil. Estados Unidos de Norteamérica.

Received for publication in 23/08/2019

Approved for publication in 15/10/2019 